\title{
Conclusions of Practical Argument: A Speech Act Analysis
}

\author{
Marcin Lewiński*
}

Received: 19 June 2019 / Accepted: 21 April 2020

\begin{abstract}
Conclusions of theoretical reasoning are assertions - or at least speech acts belonging to the class of assertives, such as hypotheses, predictions or estimates. What, however, are the conclusions of practical reasoning? Employing the concepts of speech act theory, in this paper I investigate which speech acts we perform when we're done with an instance of a practical argument and present its result in a linguistic form. To this end, I first offer a detailed scheme of practical argument suitable for an external pragmatic account (rather than an internal cognitive account). Resorting to actual examples, I then identify a class of actioninducing speech acts as characteristic conclusions of practical argument. I argue that these speech acts - promises, orders, pieces of advice, proposals, and others - differ chiefly depending on the agent of the action induced (me, us, you, them) and their illocutionary strength.
\end{abstract}

Keywords: Illocution; practical argument; practical reasoning; speech acts.

\section{Introduction}

Practical reasoning and theoretical reasoning are typically defined as, respectively, reasoning about what to do and about what to believe. Yet,

* Nova Institute of Philosophy, Nova University of Lisbon

(D) https://orcid.org/0000-0002-7218-3948

- Campus de Campolide - Colégio Almada Negreiros 1099-032 Lisboa, Portugal

$\bowtie$ m.lewinski@fcsh.unl.pt

() The Author. Journal compilation (C) The Editorial Board, Organon F.

This article is distributed under the terms of the Creative Commons Attribution-NonCommercial 4.0 International Public License (CC BY-NC 4.0). 
the seemingly innocent "about" might be quite misleading here, and in a dual sense. The distinction does not in fact pertain to 1) the content of 2) the premises which we are reasoning "about," such as when we reason (whether practically or theoretically) "about" Brexit or Donald Trump. Rather, it refers to 1) the function of 2) the conclusion of reasoning. We thus reason "about" what we conclude we can do about Brexit or "about" what we conclude we should believe about Trump. Given this, the analysis of the function of the conclusion of reasoning is, by definition, crucial. This is my task for this paper.

In this task, I will avail myself of the basic idea of speech act theory, namely, that various functions of our language use can be comprehensively elucidated via the concept of speech acts. ${ }^{1}$ This requires attention to the conclusions of our reasoning as linguistically constituted via practical argumentation - or at least linguistically represented; I give attention to this issue directly below, in Sections 2 and 3. Looking from the perspective of practical argumentation, and not just reasoning, the basic problem of this investigation can be represented as follows:

Conclusions of theoretical reasoning are assertions - or at least speech acts belonging to the class of assertives, such as hypotheses, predictions or estimates. This follows directly from standard definitions of assertives and of theoretical reasoning: both are about how things are and, as such, can be true or false. On a standard view (but see Section 2.4 for a challenge), theoretical reasoning is thus assertoric through and through: we insert various types of assertives as premises and conclude with another assertive. What, however, are the conclusions of practical reasoning? What do we do with words when we arrive at a conclusion of a practical argument? Which speech acts do we perform when we're done with an instance of a practical argument? (Other than: "I'm done!")

To answer these questions, in Section 3 I will offer a detailed scheme of practical argument suitable for an external pragmatic account (rather than an internal cognitive account). Resorting to actual examples (Section 4), I then identify a class of action-inducing speech acts as characteristic conclusions of practical argument (Section 5). I argue that these speech acts-

1 For recent accounts see (Green 2020) and (Fogal, et. al eds. 2018); for classic works see, of course, (Austin 1975) and (Searle 1969). 
promises, orders, pieces of advice, proposals, and others - differ chiefly depending on the agent of the action induced (me, us, you, them) and their illocutionary strength.

\section{What concludes practical reason?}

\subsection{Attitudes or acts of a reasoning agent}

Philosophical accounts of practical reasoning (henceforth: PR) are still dominated by the first-person perspective of a single reasoning agent (Audi 2006; Broome 2013; Davidson 1963; Gauthier 1963; Pollock 1995; Searle 2001) - even if work on collective intentions and actions is ever-more prominent (Bratman 2014; Gilbert 1990; Searle 2010; Tuomela 2013). Accordingly, the mainstream philosophical discussion over how to conclude PR revolves around the issue of the nature of the propositional attitude, or intentional state, which properly concludes PR. The conclusion is a result of reasoning from other states (premises) such as desires/intentions and beliefs (Figure 1).

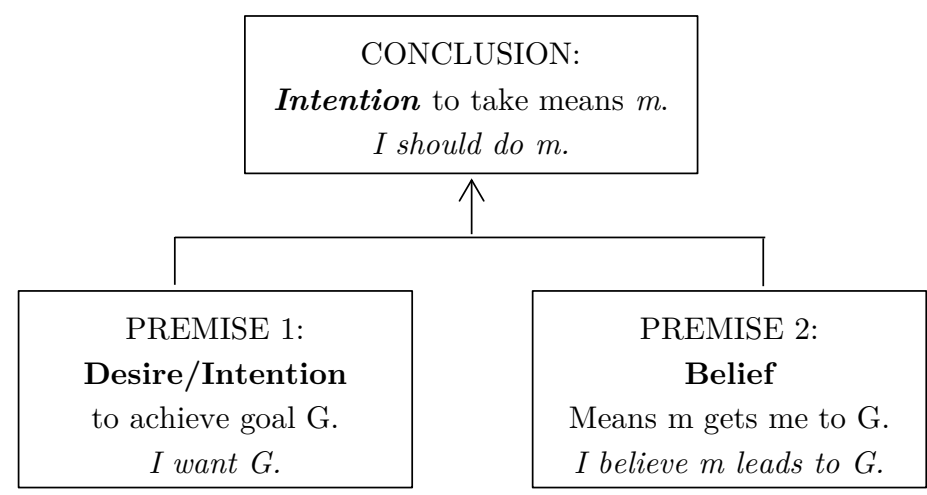

Figure 1: The basic scheme of practical reasoning

According to Searle, there is "a bewildering variety" of accounts of the elements of PR: they can be "desires, intentions, fiats, imperatives, norms, noemata, actions" (Searle 2001, 242) - and many of these can feature as 
PR's conclusions. ${ }^{2}$ From the weakest to the strongest conclusion, one can recognise the following continuum:

disposition to act (pro-attitude, secondary desire, practical judgment) decision to act (prior intention) intention to act (intention-in-action) action itself

The crucial difference of opinion exists between those who think action itself is the proper conclusion of PR (Aristotle, Nicomachean Ethics; Searle 2001, 136) and those who think this is plain wrong, for reasoning is limited to propositional entities and cannot extend beyond them - therefore an intention to act is as far as we can get (Gauthier 1963; Broome 2013).

Clearly, we are dealing here with a single reasoning agent pondering over the right course of action for her to take. This would be perfectly fine if the extrapolation from the simplest unit of individual reasoning to various forms of collective reasoning was warranted. But it seems it is not. According to Hitchcock (2002), an individualistic approach is at risk of producing a "solipsistic, egoistic and unsocial" understanding of PR. Referring to Pollock's (1995) account of PR where the basic scheme of Beliefs, Desires and Intentions is supplemented by a reasoning agent's Likings, Hitchcock describes it as solipsistic, since "there is no provision for verbal input from, or verbal output to, other autonomous rational agents, still less for back-andforth discussion, whether argumentative or non-argumentative" (Hitchcock $2002,254)$. Further, "it is egoistic, in that the function of the entire system is to make the world more to the liking of that system itself" $(2002,254)$. As a result, "nothing [...] permits rational criticism" $(2002,255)$ of an agent's hierarchy of desires and likings. Finally, the "model is unsocial, in that his [Pollock's] rational agent does not (and cannot) belong to any groups of autonomous rational agents with governance structures for making decisions about the actions of the group" (2002, 255). As Hitchcock concludes,

2 Searle is clearly echoing Davidson's classic account where the pro-attitudes constitutive of PR include "desires, wantings, urges, promptings, and a great variety of moral views, aesthetic principles, economic prejudices, social conventions, and public and private goals and values in so far as these can be interpreted as attitudes of an agent directed toward actions of a certain kind." (Davidson 1963, 686). 
"[a] comprehensive theory of good practical reasoning would have to remedy all three of these lacks" $(2002,255)$.

\subsection{The speech act of advice}

Of special importance in grasping the nature of the conclusion of $\mathrm{PR}$ is Gauthier's early work on various forms of representing the conclusion of PR, namely: practical judgement, in practical discourse. Focussing on practical discourse, and not merely practical inference, is crucial: "For it is in discourse that people actually make practical judgements, and support or criticize them" (Gauthier 1963, 50). As such, "[a]n examination of practical discourse may be expected to make clear the actual criteria used in appraising practical arguments, and hence in establishing practical judgements" (Gauthier 1963, 50). Practical discourse (practical argumentation, deliberative practices) is thus not only a display mechanism for inner practical reasoning but also an important entry point into the elements and standards of practical reasoning (Lewiński 2017). ${ }^{3}$

Gauthier's central idea is fairly straightforward:

The basic practical conversation may be formulated simply: 'What shall I do?' 'Do x!' The response is most naturally put in the imperative mood, although it need not be; one might say, 'I advise you to do x', or 'Why not do x?', or 'You should do x'. [...]

Grammatically, the imperative mood is restricted in person to the second, and the first plural, and in tense to the present. These restrictions are of considerable importance in determining the relationship between imperatives and practical judgements, which are expressed in the indicative mood, and hence in any person and any tense. (Gauthier 1963, 50-51).

3 Following Witek's (2021) terminology, practical reasoning/inference would have the "thinking-to-speaking direction of influence," while practical argumentation/discourse the "speaking-to-thinking direction of influence." However, Mercier and Sperber's (2011) idea that reasoning is for argumentation puts into question the very idea of purely discourse-independent reasons with a uniquely one-way, thinking-tospeaking direction of influence. 
Based on this, Gauthier proposes to study five broad classes of imperatives: i) commands, orders, directions; ii) instructions and directions (sic!); iii) advice, recommendations; iv) urges, exhortations; v) requests. ${ }^{4}$ While all these classes can be grammatically represented via the basic imperative phrase ("Do $x !$ "), they are obviously distinct. According to Gauthier, the paradigmatic form is advice - contrary to the other imperatives of practical discourse, the very function of advice among men is "to assist their fellows with their practical problems" (Gauthier 1963, 77): "Advice is characteristically sought as a result of practical concern. Confronted with a practical problem, a man may not only make a personal judgement of what he should do, but may also ask for the judgements of others" (Gauthier 1963, 53). The bulk of Gauthier's work is thus dedicated to analysing the conditions for successful advice and the intricate differentia specifica of advice in the broader genus of imperatives, esp. instructions, recommendations, hortations, commands and "moral counsel" (Gauthier 1963, esp. Chs. 4, 5, 10). In particular:

In giving advice, and in determining what advice to give, the adviser is expected to reason from the advisee's practical basis. In advising, we treat someone else's problem from his point of view. In recommending, we consider whether our experience is relevant to recommendee's problem, regarded from his standpoint. Thus, in arguing from the situation in which advisee finds himself to a conclusion about what he should do, the adviser must take, as premisses with practical force, those which he believes to be held by advisee. (Gauthier 1963, 54-55) ${ }^{6}$

4 See (Condoravdi and Lauer 2012) and (Portner 2018) for recent categorisations of imperatives which, while in many aspects similar, do not refer to Gauthier's work. 5 This idea has clearly Aristotelian provenance: "We call in others to aid us in deliberation on important questions, distrusting ourselves as not being equal to deciding" (Nicomachean Ethics, 1112b11).

6 Furthermore: "Directly hortatory terms, such as 'urge' and 'exhort', do not entail the commitment to concern with the problems of the person addressed that terms of advice imply. To urge someone to do something is to seek to move him to do it by open verbal means" (Gauthier 1963, 59); "Imperatives of advice concern practical problems of advisee. Imperatives of command do not. If you are authorized to command me to carry out certain actions, then it is inappropriate for me to consider 
Two important comments are immediately necessary here. First, Gauthier does not use any of the conceptual vocabulary of speech actsillocutionary forces, felicity conditions, etc. This is natural, given the timing of his work. Similarities are, of course, striking: Gauthier clearly analyses various directive speech acts (see Searle, 1975). He also specifically thanks his original supervisor at Oxford-"the late Professor J. L. Austin"-for illuminating discussions on the concept of advice. However, despite most precious insights into the nature of speech acts used in practical discourse, the lack of this specific conceptual framework is a serious limitation. ${ }^{7}$

Second, and perhaps an intellectually graver limitation, is Gauthier's understanding of practical reasoning as restricted to two basic forms: prudential and moral reasoning. Prudential problems, deriving from the practical base of an agent's individual wants and desires, "are essentially private, personal, not affecting others" (Gauthier 1963, 149). By contrast, "moral problems are not and cannot be purely personal, since they involve situations in which the interests of others are affected" (Gauthier 1963, 149). Using Hitchcock's terms adduced above, prudential discourse is thus not solipsistic (it is discourse, after all), but it is still egoistic and unsocial. Indeed, the speech acts mentioned above pertain to prudential discourse, and they are essentially private transactions between one reasoning agent (esp., advisee) and another reasoning agent (advisor), meant to solve the private practical problem of the former. In this context, advice is understandably the most central speech act. In the context of moral discourse, however, "advice" morphs into "moral counsel" by virtue of extending the content of the premisses of PR, namely, by including wants and interests of others beyond the advisee: "The schema which served for prudential practical reasoning is then adapted to the general case by substituting the extended basis, and the class of premisses with practical force derivable from it" (Gauthier 1963, 86). In this way, moral discourse would additionally not be egoistic, since "all wants of all persons are to be included in the

whether I shall benefit from the actions, or even whether to perform the actions. If you are entitled to command, I am obliged to obey. The responsibility for the performance of the actions is assumed by the commander." (Gauthier 1963, 61).

7 For a recent account of advising, building on Searle's $(1969,1975)$ formulation of the felicity conditions of the speech act of advising, see (van Poppel 2019). 
basis of [moral] practical reasoning of any agent" (Gauthier 1963, 86, emphasis in original).

However, both forms of PR studied by Gauthier remain largely unsocial. There is no room for joint, collective action and collective reasoning that is not immediately moral. Taking a walk with a friend, jointly fixing a car, or carrying a table together, are all practical problems that typically require practical reasoning and do affect others, yet do not call for moral counsel. Gauthier has very little to say about how we coordinate and resolve such issues in practical discourse. As a result, despite his undeniably relevant insights, some element is still missing.

\subsection{The speech act of proposal}

A good starting point towards investigating this missing element is to argue PR is a social - or, in principle, socializable - activity. This argument has quite some tradition in philosophy, as it characteristically connects PR to an argumentative activity of deliberation, a link stressed since Aristotle (EN). ${ }^{8}$ One main consequence of it is a shift of focus away from the internal propositional attitude of intention to some externalised and collective speech act, notably, that of proposal. ${ }^{9}$ Accordingly, the analyses of proposals have attracted some attention - especially in argumentation theory

8 See (Lewiński 2017; 2019), (Corredor 2020), (Dascal 2005), (Green 2017), and (Walton 2006; 2007). While some authors claim that this connection is a sign that "Aristotle has confused the psychological process by which a person comes to resolve a practical problem with the logical argument in which the steps leading to the resolution are formally set out" (Gauthier 1963, 26; cf. Chang, 2016), others argue this might have been a deliberate choice in Aristotle's conception, where the process of deliberation is constitutive of practical reason, and thus in-principle social and open to the back-and-forth of argumentation (Lewiński 2017; 2019; Dascal 2005).

9 Notice, though, that Broome, somewhat inconsistently, also speaks of speech acts which the reasoner performs to herself: "the speech-act you perform is the act of expressing an attitude of yours" (Broome 2013, 253). While expressing (propositional) attitudes, such as beliefs, desires and intentions, is one key job speech acts do (Green 2009; Witek 2021), they are communicative, rather than purely mental, acts which therefore always involve at least two parties, the speaker and the hearer, as well as the complex social commitments between them and larger groups (Lewiński 2021). 
(Aakhus 2006; Corredor 2020; Ihnen Jory 2015; Kauffeld 1998; Walton 2006). Crucially, proposals shift the agent of the conclusion of PR from an individual "I" or "you" to plural "we": "so I should do m" or "so you should do $\mathrm{m}$ " is reformulated to "so let us do m". ${ }^{10}$ While Gauthier was clearly aware of the fact that "the imperative mood is restricted in person to the second, and the first plural" (Gauthier 1963, 51), he focussed exclusively on the former, while having nothing to say of the latter, performed characteristically via the "let us..." construction.

Aakhus (2006) analyses proposals in deliberation as speech acts located between Searle's $(1969 ; 1975)$ commissives (such as promises) and directives (such as requests) (see Table 1). Commissives are about future acts of the speaker who, in performing the speech act, commits her/himself to this act ("I will clean the room tomorrow"). Directives are about future acts of the hearer, whom the speaker wants to get to do something ("Clean the room tomorrow, will you?!"). Proposals concern future acts of both the speaker and the hearer, and their illocutionary point is "to enlist $\mathrm{H}[$ earer] in mutually bringing about [act] A" (Aakhus 2006, 406). They would thus be typically expressed by constructions such as "Let's (clean the room tomorrow)!" or "How about we (clean the room tomorrow)?"

According to Aakhus, "[w] hen proposing, a speaker puts forward a future act that requires a joint performance by the speaker and hearer" (Aakhus 2006, 405) and, additionally, "the speaker frames the proposed actions as mutually beneficial" (Aakhus 2006, 404). In this way, proposing is a speech act through which the conclusion of $\mathrm{PR}$ is put forward for consideration in the argumentative activity of deliberation: "A proposer $(\mathrm{P})$ puts forward the proposal in part to get agreement but also to test for doubts and objections [...] that may in turn help P design a more acceptable proposal" (Aakhus 2006, 406). Therefore, proposing belongs to the kind of illocutionary acts in which "speakers necessarily or typically incur probative burdens," that is, "a speaker cannot, other things being equal, responsibly dismiss an addressee's demands for proof" (Kauffeld 1998, 247). ${ }^{11}$ What follows is that felicitous

10 In Walton's formulation, the conclusion of PR in "multi-agent deliberation" is a "practical ought-statement" (Walton 2006, 204): We ought to do it.

11 This condition is often, e.g. in (Pagin 2016), (Watson 2004), and (Williamson 1996), seen as a distinguishing characteristic of assertions-but it does not seem 
proposals concern actions which are: 1) communicated and open for discussion, thus surely not solipsistic; 2) mutually beneficial rather than purely egoistic; 3) jointly performed, and therefore social. In this way, the analysis of proposals addresses all three concerns regarding individualistic approaches to PR identified by Hitchcock (see Sec. 2.1). However, as I will argue beloweven if a paradigmatic case - proposal is only one of the possible speech acts which can convey the conclusions of PR.

\begin{tabular}{|c|c|c|c|}
\hline Act & $\begin{array}{c}\text { Request } \\
\text { (Searle, 1969) }\end{array}$ & Propose & $\begin{array}{c}\text { Promise } \\
\text { (Searle, 1969) }\end{array}$ \\
\hline $\begin{array}{l}\text { Propositional } \\
\text { Content }\end{array}$ & Future act $\mathrm{A}$ of $\mathrm{H}$. & Future act $\mathrm{A}$ of $\mathrm{H}+\mathrm{S}$. & Future act $\mathrm{A}$ of $\mathrm{S}$. \\
\hline $\begin{array}{l}\text { Preparatory } \\
\text { Condition }\end{array}$ & $\begin{array}{l}\mathrm{H} \text { is able to do A. } \\
\mathrm{S} \text { believes } \mathrm{H} \text { is able to } \\
\text { do A. } \\
\text { It is not obvious to } \\
\text { both } \mathrm{S} \text { and } \mathrm{H} \text { that } \mathrm{H} \\
\text { will do } \mathrm{A} \text { in the nor- } \\
\text { mal course of events of } \\
\text { his own accord. }\end{array}$ & $\begin{array}{l}\mathrm{H} \text { and } \mathrm{S} \text { are able to } \\
\text { contribute to the ac- } \\
\text { complishment of A. } \\
\text { It is not obvious to } \\
\text { both } \mathrm{S} \text { and } \mathrm{H} \text { that ei- } \\
\text { ther S or H can do A } \\
\text { of their own accord in } \\
\text { the normal course of } \\
\text { events. } \\
\text { That A will leave nei- } \\
\text { ther S nor H worse off } \\
\text { than not doing A. }\end{array}$ & $\begin{array}{l}\mathrm{S} \text { is able to do } \mathrm{A} . \\
\mathrm{S} \text { believes } \mathrm{S} \text { is able to } \\
\text { do } \mathrm{A} \text {. } \\
\text { It is not obvious to } \\
\text { both } \mathrm{S} \text { and } \mathrm{H} \text { that } \mathrm{S} \\
\text { will do } \mathrm{A} \text { in the nor- } \\
\text { mal course of events of } \\
\text { his own accord. }\end{array}$ \\
\hline $\begin{array}{l}\text { Sincerity } \\
\text { Condition }\end{array}$ & $\mathrm{S}$ wants $\mathrm{H}$ to do $\mathrm{A}$. & $\begin{array}{l}\mathrm{S} \text { believes } \mathrm{A} \text { will mutu- } \\
\text { ally benefit } \mathrm{H} \text { and } \mathrm{S} \text { or } \\
\text { that if it benefits } \mathrm{S} \text { it } \\
\text { will leave } \mathrm{H} \text { no worse } \\
\text { off. }\end{array}$ & $\begin{array}{l}\mathrm{S} \text { intends that in utter- } \\
\text { ing to do } \mathrm{A} \text { he is under } \\
\text { the obligation to do A. }\end{array}$ \\
\hline $\begin{array}{l}\text { Essential } \\
\text { Condition }\end{array}$ & $\begin{array}{l}\text { Counts as an attempt } \\
\text { to get } \mathrm{H} \text { to do } \mathrm{A} .\end{array}$ & $\begin{array}{l}\text { Counts as an attempt } \\
\text { to enlist } \mathrm{H} \text { in mutually } \\
\text { bringing about } \mathrm{A} \text {. }\end{array}$ & $\begin{array}{l}\text { Counts as an attempt } \\
\text { to commit } \mathrm{S} \text { to do } \mathrm{A} \text {. }\end{array}$ \\
\hline
\end{tabular}

Table 1: Felicity conditions for requesting, promising and proposing (Aakhus 2006, 406)

right. Quite the opposite, each speech act can be challenged and its felicity conditions tested, whereby some kind of "proof" by the original speaker must be provided. This proof would typically relate to its sincerity and preparatory conditions. This applies even to expressives: "Ouch!"—_No, this cannot really hurt, don't exaggerate." See also below, Section 2.5. 


\subsection{Proviso: Any speech act can conclude PR}

All speech acts, including assertive speech acts, are, well, acts. They are intentionally performed human acts, based on some kind of linguistic, cultural and societal conventions. ${ }^{12}$ As such, while they may be performed without profound deliberation - think of common expressives such as "Ouch!" or "Sorry!" - speech acts typically result from some prior judgment. That is, we need to practically reason, inside of us, to perform this and no other speech act in this very situation. In any communicative activity, we thus constantly conclude our internal deliberations with a conclusion "I should say $X$ now" or "I should perform speech act of the kind $Y$ (apologise, deny, object to, approve)." In this respect, there is similar PR behind commissive speech acts such as "So I shall catch the 2:30 train to London" and assertions such as "So the cat is on the mat." In Searle's words:

There is thus a sense in which all reasoning is practical, because it all issues in doing something. In the case of theoretical reason, the doing is typically a matter of accepting a conclusion or hypothesis on the basis of argument or evidence. Theoretical reason is, thus, a special case of practical reason. (Searle 2001, 90-91)

Yet this sense is indeed special and perhaps trivial: speech acts are our intentional contributions to communicative activities and are all, in this sense, direct executions of some inner practical inference regarding our communicative involvement (roughly, our communicative plan).

Importantly, this practical communicative reasoning can be either a matter of descriptive psychology or of normative reconstruction. In descriptive studies, the behind-the-scenes working of practical inference in specifically argumentative communicative activities has been well documented by Hample (2005), Mercier and Sperber (2011), Paglieri (2013), and others. In general, forms of instrumental or strategic PR, characterised by a costbenefit analysis of what and how efficiently one can achieve with a given argumentative contribution, have been identified. Arguers decide to perform and edit their arguments based on considerations such as chance of

12 See (Austin 1975), (Strawson 1964), and (Searle 1969); for a recent overview, see (Harris et al. 2018). 
success, identity and relation management, negative and positive politeness, situational appropriateness, as well as truth and relevance of their arguments. ${ }^{13}$ While these results have not been cast in the language of PR about what to do, they clearly can be.

But the PR behind the performance of a given speech can also be understood in terms of normative reconstruction that can be paraphrased as: "a speaker who performs the act of $\varphi$-ing is to be ready to rationalize her speech act and reconstruct a practical reasoning whose conclusion would be So I should have $\varphi$-ed." This reconstruction would thus reveal the structure of reasons motivating a speaker's performance of this, and no other, speech act. As such, it would always be an explanatory reconstruction having the structure of PR. This should not be confused with the possible reconstruction of the reasons justifying my performance of a given speech act. Theoretical reasons need justification "on the basis of argument or evidence" (Searle 2001, 91) and are concluded via any of the speech acts belonging to "the 'assertive' family": from mere guesses, to justified presumptions and conjectures, to strong assertions grounded in knowledge (Green 2009). Practical reasons, by contrast, need justification grounded in values, desires, preferences, and a comparative assessment of means, and are concluded via any of the action-inducing speech acts described below in Section 5 .

Take a simple example: I have knowledge of the contextually required standard of a certain finding F. I am thus justified in issuing a straightforward assertion F. However, given this finding directly challenges results of a revered professor and my close colleague X, I decide to put forth my finding with the illocutionary force of a conjecture. I thus downgrade my assertive speech act for reasons of mutual respect and amicable cooperation. My conjecture is thus theoretically justified, and excessively so, by the evidence I have in hand, and practically motivated by concern for values my community (allegedly) holds dear. All this is different from performing specific speech acts as conclusions directly justified by PR: an issue this study focusses on.

To conclude, there is some practical inference, even if largely unconscious, behind performance of any speech act, including assertives and all argumentative speech acts. The reconstructible practical inference leading

13 For a discussion, see Chapter 4 of (Hample 2005). 
to the use of speech on a given occasion is, however, quite different from performing speech acts presented as conclusions of one's deliberate practical reasoning. Concluding that "Aristotle could well have written Rhetoric all by himself" requires very different supporting arguments than the conclusion "let's employ Aristotle." ${ }^{14}$

\subsection{Counter-Proviso: Only assertives conclude our reasoning, whether theoretical or practical}

Let's consider the following example, due to van Eemeren and Grootendorst (1984, 97-98).

Let's take an umbrella, or do you want to get wet?

It doesn't take much imagination, nor work, to reconstruct this utterance as a commonly experienced instance of PR. The speaker starts with a conclusion-"Let's take an umbrella"- that expresses an intention to act in a specific way. This conclusion is grounded in the desire-here explicitly expressed via a rhetorical question - that "we don't want to get wet." Unexpressed is the (obvious, hence the enthymematic form) belief that in a $20^{\text {th }}$ century Western society one good (perhaps the best, or at least satisfactory) way of not getting wet while going out is using an umbrella. Further, the conclusion here is clearly a speech act of proposal, just as defined above, involving a joint action and matching desires of both speaker and hearer (walking together in the rain, staying dry under the umbrella). ${ }^{15}$

Van Eemeren and Grootendorst (1984, 98), however, see this sort of interpretation as "erroneous," at least within their framework of speech acts in specifically argumentative discussions:

The utterance 'Let's take an umbrella' should not be seen as the expressed opinion at the centre of the dispute that the speaker is trying to resolve with the aid of the utterance 'or do you want to get wet?' Rather it is a statement indicating that the speaker recognizes the possibility of a dispute arising about his proposal.

14 I am indebted to Maciej Witek for discussion in this section.

15 See (Gilbert 1990) for a classic account of this minimal kind of collective activity of walking together. 
This dispute might then be centred on the question of whether the proposal was a good one. The expressed opinion on which this particular dispute is centred is not formulated explicitly, but that is always possible. For example, the speaker might say: 'It is advisable to take an umbrella.' This statement is an elementary illocutionary act of the assertive type.

In fully externalized discussions the expressed opinions and the argumentation must always in our view consist of elementary illocutions belonging to the class of the assertives. Expressed opinions and argumentations consisting superficially of illocutions of some other type must first be analysed in such a way that it is clear exactly what assertives are involved. If these expressed opinions and argumentations could not be construed as assertives a resolution of the dispute would be impossible, since it is only possible to resolve disputes thanks to the specific committedness associated with the performcance of assertives. (van Eemeren and Grootendorst 1984, 98, italics in original)

To understand their misgivings here, we need to grasp "the specific committedness" of assertives. According to van Eemeren and Grootendorst, "the illocutionary point of the members of the class of assertives [is] to commit the speaker (to a greater or lesser degree) to the acceptability or unacceptability of the expressed proposition" (van Eemeren and Grootendorst 1984, 97, italics in original). Further, this "specific committedness" results in the "obligation to defend" the acceptability of a speech act, which they consider "to be a general feature of assertives, distinguishing them as a class from other illocutionary acts" (van Eemeren and Grootendorst 1984, 96). ${ }^{16}$

As already mentioned, these claims are made in their task of developing a speech act-based theory of idealised argumentative discussions. What is at stake in such discussions is defensibility of a standpoint $(+,-, \varnothing$; this is a conversational equivalent of a conclusion) in respect of an expressed opinion (O). Symbolically,

$$
+/(\mathrm{O}(p))
$$

16 See also (Green 2009), (Houtlosser 1998), (Pagin 2016), (Watson 2004), and (Williamson 1996). 
reads: my standpoint in respect of $\mathrm{O}$ is that $\mathrm{O}$ is the case (see van Eemeren and Grootendorst (1984, 114; '-' would mean "isn't the case", and ' $\varnothing$ ' "I have no standpoint on the issue"). More precisely, we should add: my standpoint in respect of $\mathrm{O}$ is that $\mathrm{O}$ is an acceptable assertive with respect to its propositional content $p$. As we could see, this extends to other classes of speech acts, so for example,

$$
+/(\mathrm{O}(\mathrm{P}(p)))
$$

would read: my standpoint in respect of the expressed opinion $\mathrm{O}$ that the proposal $\mathrm{P}$ to take an umbrella $(p)$ is good, is that $\mathrm{O}$ is an acceptable assertive with respect to the Proposal's being good.

Three arguments can be lodged against this, otherwise interesting, reconstruction of the conclusions of PR. First, each and every speech act would, at least for the purposes of argumentation analysis, be, eventually, an assertive. ${ }^{17}$ A reduction of all speech acts to assertives is arguably not the claim van Eemeren and Grootendorst propound. Instead, they seem to defend a weaker claim that when we conclude an argument by making an utterance that in a non-argumentative context would be naturally taken to constitute the performance of a non-assertoric act only, the actual function of the utterance is that of making an assertion about the non-assertoric illocution in question. But even this weaker claim undermines the "central insight" of speech act theory, namely, that "language is a medium for many kinds of action, but its superficial uniformity tends to mask this fact" (Harris et al. 2018, 1). Indeed, van Eemeren and Grootendorst's definition of assertives seems to point to a very "general committedness" of speech acts, rather than "specific committedness" of assertives: all speech acts have satisfaction conditions (truth con-

17 This should not be confused with Bach's (1975) argument that "performatives are statements too" (note the "too"), on the ground that performative utterances self-referentially state their illocutionary force and the vehicle for that force, the very performative utterance itself. This can be made explicit by adding an assertoric formula such as: '[In uttering this sentence,] I order you to leave' (Bach 1975, 234). As such, speech acts other than assertives "comprise two simultaneous illocutionary acts" (Bach 1975, 229); for further discussion, see also (Searle 1989), (Bach and Harnish 1992), and (Reimer 1995).

Organon F 28 (2) 2021: 420-457 
ditions, fulfilment conditions, "answerhood" conditions) and as such all obligate the speaker to defend these conditions when challenged, thus justifying the speech act's acceptability. Second, their approach is prone to infinite regress: I Propose $p$, and my expressed Opinion is that $\mathrm{P}$ is a good proposal, and my Standpoint is that my $\mathrm{O}$ is acceptable and... why not: Claim that my Standpoint is correct, and then Endorse the Claim, and Assert the Endorsement as true, etc.? Third, any "assertorification" of directive and commissive speech acts - proposals, recommendations, (moral) imperatives, pieces of advice - following the 'It is advisable to take an umbrella' gloss would need to seriously tackle the issue of moral descriptivism / realism. "It is true that 'it is not good to kill people" as a gloss of "Thou shalt not kill" carries a heavy burden of proof that a simple statement that "ethical, aesthetic or other normative statements" (van Eemeren and Grootendorst 1984, 96) can be treated much in the same way does not quite carry.

Shortly, the idea that PR (just as any other form of linguistically expressed reasoning) always concludes in some kind of assertive is not exactly defensible. It is also rather cumbersome, and not very speech-acty (see also Jacobs 1989). There is, however, an important intuition in van Eemeren and Grootendorst's interpretation of proposals: they should be defensible as "good" proposals. This, I argue in the next section, is an inherent feature of PR.

\section{Detailed scheme of practical argumentation}

Before examining the various forms of conclusion of $\mathrm{PR}$ - which, when publicly performed, can better be called practical argumentation (henceforth: PA) - it seems necessary to understand what PA in general consists of. ${ }^{18}$ The scheme of PA presented in Figure 2 stems from a rich literature on practical argument in philosophy, Artificial Intelligence, and argumentation theory (Audi 2006; Broome 2013; Davidson 1963; Gauthier 1963; Pollock 1995; Searle 2001; Walton 2006; 2007; see Lewiński 2015; 2017 for a more detailed

18 The publicity element is more than a mere mode of presentation. Publicity of practical arguments invokes socially and institutionally recognizable commitments and, as such, can generate "desire-independent reasons for action" and forms of collective, rather than only individual, intentionality (Searle 2001; 2010). 
discussion). In particular, it is derived from a useful representation of PA by Fairclough and Fairclough (2012). While referring to their work for an analysis of all the premises constituting the scheme (Circumstances, Goal, Values), I will briefly mention five basic advantages of the scheme, focussing further on the last one: the speech acts which can conclude PA.

CONCLUSION: ACTION-INDUCING SPEECH ACT (PROPOSAL, PROMISE, ADVICE: e.g., LET'S DO M!)

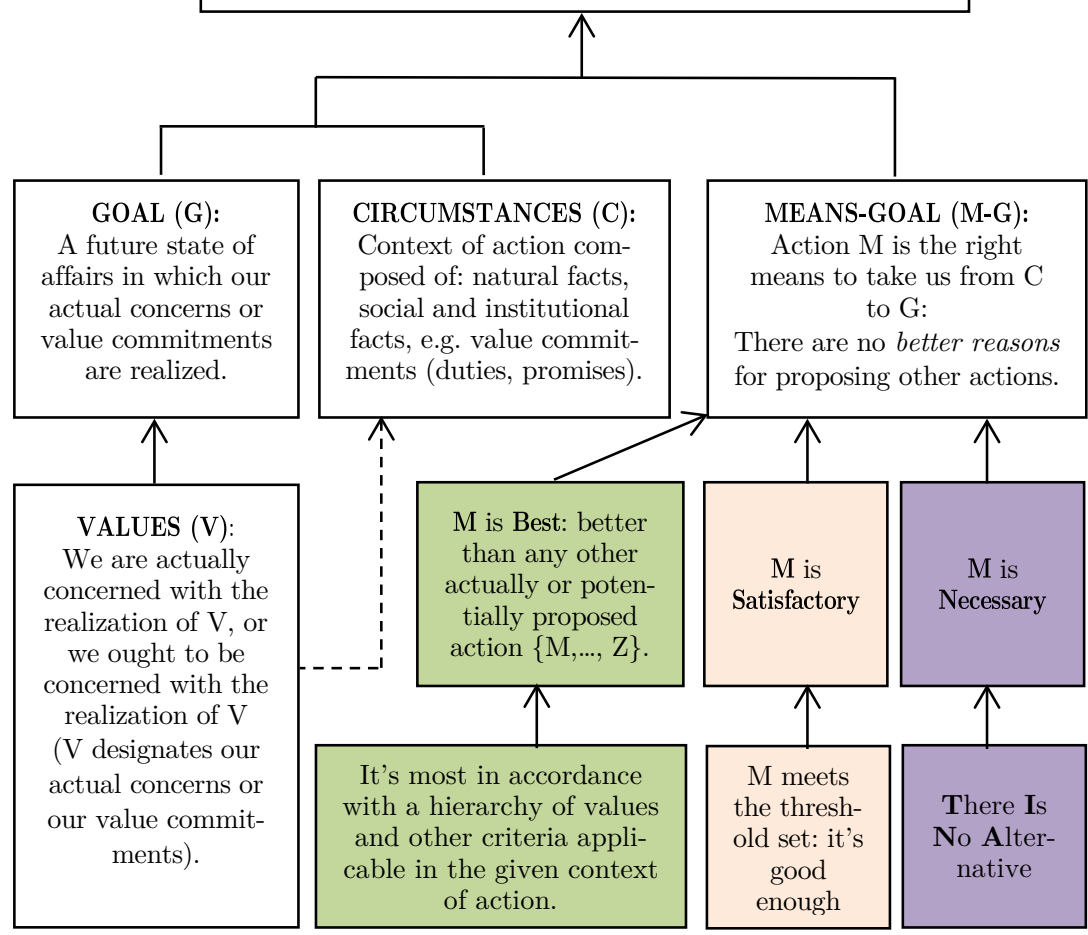

Figure 2: The scheme of Practical Argumentation Derived from: Fairclough and Fairclough (2012)

Possible, contextually-determined decision criteria: direct or indirect costs and benefits (negative and beneficial consequences / side effects) • opportunity costs • 


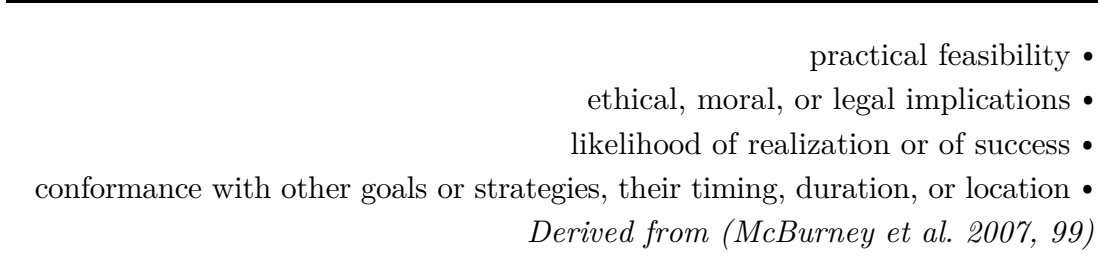

First, the scheme shapes the framework of relevance for (multi-party) deliberation. Typically, different parties argue for the contextual betterness of their proposals for action $\{\mathrm{M}, \mathrm{N}, \mathrm{O} \ldots \mathrm{Z}\}$ (see the "M is Best" box). Their deliberation develops then as an argumentative polylogue (Lewiński and Aakhus 2014; Lewiński 2017; 2021) along the lines of possible disagreements over the various elements of the structure (basic premises, inference rules and contextual criteria).

Second, the scheme distinguishes between context-independent and context-dependent elements of PA. Its basic general structure (as per Fairclough and Fairclough: all the white boxes in Figure 2) remains constant, while contextual criteria for choosing "the right means" (below the diagram) fluctuate.

Third, the scheme clarifies the notion of the means-goal premise. This premise is grounded in one of the three basic inference licences warranting the choice of "the right means" taking us from the current (unwelcome) Circumstances to the (desired) Goals. We can thus warrant our conclusions by issuing a comparative claim (Chang 2016) that either the means are necessary, or that they are satisfactory (good enough), or that they are the best among all the possible alternatives. ${ }^{19}$

Fourth, it provides a new account of how to criticise and evaluate PA. It clearly demarcates the attacks on the main premises (Circumstances, Goals, Values, Means-Goals), from those concerning context-dependent decision criteria, and from criticisms of the inference licences related to the type of inferential step made (necessary, satisfactory, or the best means) (see Lewiński 2017 for further discussion).

Fifth, the scheme defines its conclusion in terms of a class of actioninducing speech acts, thus pointing to a "unity in diversity" of what we can argue for in PA.

19 For a detailed analysis, see (Lewiński 2015) and (Lewiński 2017). 
I will now apply this scheme to the analysis of an actual case of complex practical argumentation and then discuss in detail the last point.

\section{Case study: Keep it in the ground!}

On the 16th of March 2015, the British newspaper The Guardian launched a media campaign to divest (dis-invest) from fossil fuels such as coal, oil and gas. The campaign was entitled "Keep it in the ground" and included, at its start, a very short petition, a "note from Alan Rusbridger, [The Guardian's then] editor-in-chief", a "full story" in which Rusbridger presents an elaborate argument for the petition, as well as other multimedia materials (videos, frequently asked questions, interviews, reportage) related to the dangers of our massive continuing reliance on fossil fuels. ${ }^{20}$ These texts, while originating in the same source, contain various examples of illocutionary acts concluding practical argument.

Let me start with a little note on the very slogan of the campaign: "Keep it in the ground." As an utterance in an imperative mood, it seems to be addressed to others as a directive speech act explicitly identified as (a part of) "petition" (a formal request? Appeal? Plea?). However, given the nature of such campaigns, and the immediate contextual and co-textual information (see below), it can also be understood as elided "( We should) keep it in the ground" or, even better, "(Let us) keep it in the ground"-by analogy with "(Let's) give peace a chance" and other such slogans. Here, the addressee - the agent of PA - is the first plural, inclusive we.

In what follows, I focus on Rusbridger's "full story" entitled: "The argument for divesting from fossil fuels is becoming overwhelming." ${ }^{21}$ This "story" or "argument" - in fact, a well-structured complex argument-is introduced with the following lead:

20 See http://www.theguardian.com/environment/ng-interactive/2015/mar/16/keepit-in-the-ground-guardian-climate-change-campaign, last consulted on the $6^{\text {th }}$ of January 2021.

21 See https://www.theguardian.com/environment/2015/mar/16/argument-divesting-fossil-fuels-overwhelming-climate-change, last consulted on the $6^{\text {th }}$ of January 2021. All following quotations are from this source.

Organon F 28 (2) 2021: 420-457 
As progressive institutions, the Gates Foundation and Wellcome Trust should commit to taking their money out of the companies that are driving global warming, says the Guardian's editor-inchief as he launches our climate campaign.

As is appropriate for a journalistic article, it starts with a conclusion. Here, it is clearly a conclusion of a PA - that some agents (the Gates Foundation and Wellcome Trust) "should" undertake certain actions ("should commit to taking their money out of the companies that are driving global warming").

According to Rusbridger, "[t] here are two arguments in favour of moving money out of the biggest and most aggressive fossil fuel companies - one moral, the other financial." In saying this, he explicitly refers to two basic types of PR recognised in philosophy: on the one-hand, moral or value-based reasoning, and on the other hand, instrumental, prudential, strategic or means-end reasoning. ${ }^{22}$ The moral argument is analogous to "the push to pull money out of tobacco, arms, apartheid South Africa-or even slavery." Investing big money in the fossil fuel business, even if profitable, is per se a bad thing to do-just like making money from arms or slave trade is. The chief value in the fossil fuel argument is intergenerational justice, that is, "concern for future generations": through our current recklessness, we are burdening the future generations with all the negative consequences of climate change (see Campos 2018). The Guardian's financial (or "pragmatic") argument is, interestingly, much more profoundly argued for, likely with the view towards the target agents of change, financial managers. This argument is best summarised in a quote from the Bank of England's deputy head of supervision for banks and insurance companies, Paul Fisher: "As the world increasingly limits carbon emissions, and moves to alternative energy sources, investments in fossil fuels - a growing financial market in recent decades - may take a huge hit." That is to say, those who do not care about the moral implications of climate change per se, or even do not believe in it at all, might be driven out of further investment by prudential risk-assessment.

22 See (Gauthier 1963), (Fairclough and Fairclough 2012), and (Walton 2007). 
The "Keep it in the ground" campaign - as is appropriate for any other campaign - has a precise target: managers of endowments, investment and pension funds and, very specifically, the Gates Foundation and Wellcome Trust. It is clear in the text, though, that the problems of climate change policies and energy models based on fossil fuels have a number of other relevant stakeholders (see Rodrigues, Lewiński, and Üzelgün 2019). All of them can potentially be the target of the campaign, the addressees of its arguments and, eventually, the agents of the conclusion of the argument. Rusbridger mentions that at first The Guardian thought of addressing "governments" and "politicians" in general ("MPs, presidents, prime ministers and members of congress") - but political action on climate change has proven far from satisfying: "the people who represent us around the UN negotiating tables have moved inches, not miles." That's why they decided to address the above-mentioned big institutional investors instead. Another stakeholder in the "story" are the scientists, here endowed with authority and treated with reverence: "If only science were enough [...] finance will eventually have to surrender to physics [...] the physics is unarguable." Of course, the general public is another crucial stakeholder-here, it is divided into present and future generations, with the responsibilities laid on those who can decide and act now. Finally, there are the fossil-fuel companies' directors, who - by the logic of global capitalistic economy - are compelled to "behaviour that is overwhelmingly driven by short-term returns."

We can pretty straightforwardly reconstruct the complex structure of PA from Rusbridger's argument which, in this case, is remarkably explicit. ${ }^{23}$ The current Circumstance is that of a climate change crisis caused by the overreliance on fossil fuels. This premise is briefly stated in the very first sentence of the piece: "The world has much more coal, oil and gas in the ground than it can safely burn." To address, or at least attenuate, this crisis we need to strive for a concrete Goal: " $80 \%$ of the known coal reserves will have to stay underground, along with half the gas and a third of the oil

23 As correctly noted by one of the anonymous reviewers, many public arguments have implicit premises to reconstruct - a major challenge for argumentation analysis - while "some instances of practical reasoning in the public sphere have explicit premises and implicit conclusions (the encouragement for an action is conversationally or conventionally implied)." This complication does not directly affect this very case.

Organon F 28 (2) 2021: 420-457 
reserves." Attaining this goal is necessary "if we and our children are to have a reasonable chance of living stable and secure lives 30 or so years from now." In general, the main Values and duties underlying the entire argument are "concern for future generations," "the protection of the public," "human health and science." But which means can be conducive to reaching this Goal and embodying the Values? As already mentioned, in The Guardian's view the best action to take ("the best" Means-Goal premise) is to directly call to divest from major fossil fuel companies-rather than, for instance, "campaigning for a paragraph to be inserted into the negotiating text at the UN climate talks in Paris this December" (see Lewiński and Mohammed 2019). Appropriately for deliberations, different options are thus considered and one is chosen as the option.

Finally, let us look at the Conclusions of the argument. These are explicitly indicated with the "so" connective:

So we ask that the Gates Foundation and Wellcome Trust commit now to divesting from the top 200 fossil fuel companies within five years. And that they immediately freeze any new investment in the same companies.

This, however, is not the only conclusion of the text: "We will, of course, suggest that the Guardian Media Group does the same, and keeps you informed about its own deliberations and decisions." Finally, the readers are requested to act on the argument too: "Please sign, retweet and generally spread news about the petition."

Shortly, we have here a rather motley assortment of conclusions, at least when compared to a typical first-person-singular conclusion of most PR, as examined in philosophy ("so I shall take the 2:30 train to London"). What can be done about it?

\section{Conclusions as speech acts}

I have already argued that a speech act approach can bring about the required level of nuance to our understanding of the conclusions of PA. Indeed, Austin's (1975) initial distinction between fact-relevant constatives 
and action-relevant performatives can be understood against the background of the distinction between theoretical and practical uses of reason: we constate on the basis of our theoretical reasons and we perform of the basis of our practical reasons. ${ }^{24}$ Importantly, while the constative-performative distinction does not mirror differences between assertive and non-assertive speech acts as later elaborated by Austin himself and many others, e.g., Urmson (1977), there is a sense in which the dichotomy between theoretical and practical reason permeates the two. "Assertion and its cousins," such as conjectures, presumptions or guesses are all truth-relevant speech acts, whose norms require a psychological state of belief or at least acceptance, justified by evidence of an adequate sort. ${ }^{25}$ As briefly put by Stalnaker, "[t]o accept a proposition is to treat it as true for some reason" (2002, 716), and this reason is theoretical reason. Some of the non-assertive speech acts, by contrast, are justified by practical reason and performed as its conclusion.

Against this background, the central question of this paper can be formulated as follows: Which speech acts "convey" or "express" the conclusion of practical reasoning (PR) externalised in a text, that is, of practical argumentation (PA)?

As a preliminary, consider Searle's claim that "to function in deliberation a reason must be for a type of action, it must be for the agent, and it must be known to the agent" (Searle 2001, 99). PA, being public, takes care of the last condition all by itself: the reasons are openly presented so - as long as the "normal input and output conditions" for communication obtain (Searle 1969, 57) - they are known to the agent. What remains to be

24 As is well known, Austin in fact did not endorse this distinction: his work instead shows that he either abandoned it in favour of the analysis of the locutionary/illocutionary/perlocutionary acts or, as Sbisà (2007) argues, from the very beginning presented it rather as a premise of a reductio ad absurdum argument: assuming that the constative-performative dichotomy holds leads to absurd consequences (e.g., statements too function as performatives leaving the set of pure constatives empty), so it cannot be right.

25 Strong for assertions, weak for guesses; for a discussion, see (Green 2009) and (Witek 2021). 
analysed are the type of action and the type of agent that practical argumentation is "for."

For Fairclough and Fairclough (2012), the conclusion of PA has the form: "Claim for action: Agent (presumably) ought to do A." In their discussion of this point (Fairclough and Fairclough 2012, 45-46), the Faircloughs notice that the first-person-singular analyses of PR opportunistically conceal the fact that the arguer and the agent of action are not always the same. We can, and often do, argue practically with someone else's action in the conclusion ("All things considered, the best thing to do now is for you to go and apologise"). Shortly, the philosophers' agent-self (Searle 2001, 99), can be a self different than the arguer-self. ${ }^{26}$

The scope of the claim for action is further complicated by formulations such as "should" or "ought to." These are notoriously ambiguous, even underdetermined - if not semantically, then surely pragmatically. ${ }^{27}$ In everyday spoken language we manage this ambiguity very well trough skilful, even if unconscious, use of prosody and contextual information. Compare:

You should just let him go - a friendly suggested advice.

You should let him go please - an appeal or entreaty.

You should let him go right now - a command.

(Note that in spoken discourse, the illocutionary force equivalent to "just," "please," and "right now" can be conveyed solely by prosodic elements, such as rising/falling intonation or accent.)

Even in such simple examples the pragmatic analysis of expressions such as "should" leaves the notion of a "claim for action" largely underspecified. The analysis in the previous section likewise identified that, quite tellingly, The Guardian editors conclude their arguments with varied "claims for actions" by agents other than themselves. What exactly can this "claim" be?

As analysed above, in the case of the conclusion of PA, the speech act of proposal has been considered a paradigm case in (Aakhus 2006), (Cor-

26 This limitation to the agent-self has clear Aristotelian roots: "Deliberation is about the things to be done by the agent himself" (EN, 1112b32).

27 See esp. (Portner 2007) and (Portner 2018). 
redor 2020), (Ihnen Jory 2016), (Kauffeld 1998), and (Walton 2006). Proposals are speech acts located between commissives (such as promises) and directives (such as requests). ${ }^{28}$ Due to this peculiarity they belong - next to bets, offers and bids - to a class of speech acts inescapably requiring an action of both the speaker and the hearer. Taken together, commissives, directives, and their hybrids (such as proposals or offers) form a class of what I will call action-inducing speech acts (see Table 2) - in opposition to assertives (representatives), expressives and declarations. Action-inducing speech acts are characterised by their world-to-words direction of fit (Searle 1975), ${ }^{29}$ as their point is to get an agent (whether "I", "you", or "we") to

28 Searle and Vanderveken treat proposals, somewhat in passing, as instances of directives: "Thus, for example, the illocutionary force of accepting (a proposal, an invitation, etc.) has one more preparatory condition than the illocutionary force of commitment to a future action, namely that the speaker has been given a directive that allows for the possibility of refusal" (Searle and Vanderveken 1985, 66, italics added). For reasons described in Section 2.3 this doesn't seem right. That proposals do more than direct others to do something is clear in that they are, inherently, also conditional promises (just like bets and offers): Let's go for a walk = You should go for a walk + If you do, I will come join you. Requests and invitations, discussed by Lance and Kukla $(2013,461)$, do not have this conditional commissive component, but at most some weak conditional expressive component: Do something for me + If you do, I'll be happy (the terms are mine). It is precisely this addition of a conditional commissive component that turns acts such as requests or invitations into offers and proposals. Compare a) with b):

Parent to a child:

a) Clean your room, please!

b) Clean your room - and I'll let you play games the whole night!

If the speech act is perlocutionarily successful (i.e., the child cleans the room), the child's natural response to b) would be: "I've cleaned the room, can I turn on my PlayStation now?" If the parent hesitates ("Well..."), the child's reaction would almost certainly be "You promised!"

29 This, of course, has not escaped Searle's attention: "Since the direction of fit is the same for commissives and directives, it would give us a more elegant taxonomy if we could show that they are really members of the same category. I am unable to do this [...] and am left with the inelegant solution of two separate categories with the same direction of fit" (Searle 1975, 356); see also (Searle 2001). Lance and Kukla (2013) characterise promises as "reverse imperatives", since both these types "oblige 
perform an action that will bring the world into a state captured in the intentional content of the speech act. (By contrast, the goal of assertive speech acts with the words-to-world direction of fit is to capture in their content some existing state of the world.) ${ }^{30}$ Naturally, so to speak, it is exactly speech acts with an "upward" (world-to-words, world-to-mind) direction of fit that $\mathrm{PR}$ is "about." Given their different direction of fit, the similarity between practical and theoretical reason breaks:

The difference between theoretical and practical reason is in the direction of fit of the conclusion: mind-to-world, in the case of drawing a conclusion from evidence or premises, and world-tomind, in the case of forming a decision and hence an intention on the basis of considerations. (Searle 2001, 91)

Now, the elements of the class of action-inducing speech acts can be distinguished, as discussed above, along two dimensions: (1) their primary agent: the speaker, the hearer ${ }^{31}$, or both; and (2) their illocutionary strength, ranging from the cancellable and nearly off-record to fully endorsed and on-record. ${ }^{32}$ Together, these two axes create an ordered matrix of "claims for action" - or speech acts which can conclude PA (Table 2).

someone to do something for someone" (Lance and Kukla 2013, 458-459, fn. 3). In his proposal challenging the very bases of Searle's taxonomy of speech acts, Hanks (2018) treats all the speech acts with a world-to-word direction of fit as a "unified category" with an "imperative propositional content," regardless of whether they involve commitments of a speaker (as in promises) or a hearer (as in orders). See (Green 2018) for a challenge to Hanks's challenge.

30 Note that for Searle (1975) expressives have no direction of fit at all, while declarations have dual direction: both words-to-world and world-to-words.

31 For the current purposes, it is inconsequential to carefully distinguish between the directly addressed Hearer ("you") and some potential, indirect Hearers or bystanders, such as third parties ("s/he", "they"). These differences do not affect the analysis proposed here - they do, however, play a significant role in understanding how speech acts function in a multi-party $(n>2)$ context; see (Clark and Carlson 1982), (Levinson 1988), and (Lewiński 2021).

32 Jacobs and Jackson (1983) study some weak directive speech acts (such as "indirect requests," "hints and prompts" and even seemingly "innocent remarks") and place them "on a continuum according to the degree to which the act-type is dissociated from the illocutionary force of a [direct] request" (Jacobs and Jackson 1983, 285). 


\begin{tabular}{|c|c|c|c|}
\hline Agent Strength & $\begin{array}{c}\text { Weak } \\
\text { (suggesting) }\end{array}$ & $\begin{array}{c}\text { Neutral } \\
\text { (committed) }\end{array}$ & $\begin{array}{l}\text { Strong } \\
\text { (solemn) }\end{array}$ \\
\hline $\begin{array}{c}\text { I / We } \\
\text { (exclusive) } \\
\text { commissive }\end{array}$ & $\begin{array}{c}\text { Declaration (of } \\
\text { intention) }\end{array}$ & Promise & $\begin{array}{c}\text { (Joint) Vow, } \\
\text { Oath, Pledge, } \\
\text { Guarantee }\end{array}$ \\
\hline $\begin{array}{l}\text { You / They } \\
\text { Directive }\end{array}$ & $\begin{array}{c}\text { Recommenda- } \\
\text { tion, Advice, } \\
\text { Invitation }\end{array}$ & $\begin{array}{c}\text { Request, Ap- } \\
\text { peal, Warning, } \\
\text { Instruction }\end{array}$ & $\begin{array}{c}\text { Order, } \\
\text { Demand, Plea, } \\
\text { Call, Entreaty }\end{array}$ \\
\hline $\begin{array}{l}\text { We (inclusive) } \\
\text { commissive/di- } \\
\text { rective }\end{array}$ & Suggestion & $\begin{array}{c}\text { Proposal, } \\
\text { Offer }\end{array}$ & $\begin{array}{c}\text { Bid, Contract, } \\
\text { Call }\end{array}$ \\
\hline
\end{tabular}

Table 2: Action-inducing speech acts as conclusions of practical argumentation

What is common to these various action-inducing speech acts is, of course, that they can all be complemented with the phrase "to do A": "I promise to do A," "I advise you to do A," "we guarantee to do A." Their strength - here divided for illustrative purposes into three levels - can quite straightforwardly be grasped by our ordinary intuitions: "I've thought about it a lot and: maybe we can go and apologise? / let's go and apologise / we must go and apologise."

Given these distinctions, we can now more precisely characterise the explicit conclusions of The Guardian's campaign: First, its very title"Keep it in the ground"-in the interpretation suggested above, takes as an agent the inclusive we. It is, in terms of speech acts, a joint proposal or call: neutral-to-strong combination of a directive (you should) and a commissive (we should too). ${ }^{33}$ Second, the main conclusion is addressed to "them" - the

33 While paradigmatically calls would be "second-person calls" (Lance and Kukla 2013), they can also be "inclusive we" calls, such as in "I call on all of us gathered 
Gates Foundation and Wellcome Trust - and explicitly identified as a (second-person) "call," a strong directive speech act. Third, "[we] the Guardian Media Group" - the exclusive we (us) - concludes the argument with a declaration of intention or "suggestion," a weak commissive speech act. Finally, "you," "the readers" are requested to spread the news. This is a conclusion expressed through a directive speech act, of a rather neutral force (it is neither only suggested nor strongly demanded or called for).

\section{Extensions and challenges}

In this paper I mostly did two things. I asked which illocutionary acts "convey" or "express" the conclusion of practical reasoning and I responded these are various action-inducing speech acts. This broad category of acts shares the world-to-word direction of fit and can be preliminarily organised by the agent of the action induced (not to be confused with the concluder of the practical argument) and the illocutionary strength of the act. But between these two things I also reviewed various other takes on what the nature or function of the conclusion of practical argument could be (to intend, to advise, to propose, to state), proposed one possible scheme of practical argument, and briefly analysed some naturally occurring instances of practical argument with their varied conclusions. In this final section, I start dealing with some possible challenges to the account offered, but with an eye towards useful extensions.

The most common formulation of the conclusion of practical argument contains the somewhat enigmatic expression "I should" / "I ought to" perform a certain action. In this way, PR ends with something like a moral obligation or imperative of the individual agent-self. Accordingly, it is the "I / exclusive we" form that constitutes the traditional area of philosophical investigation into practical and moral reasoning. Both the actions and obligations of single and, more recently, collective subjects are treated in detail far exceeding this work. However, for speech act theorists such as Searle, reasons for action and their conclusions are best understood not through

here to exercise maximum restraint." In this latter case, they are pragmatically equivalent to "We [inclusive] must exercise maximum restraint." 
some external ethical systems containing moral obligations "I" or "we" should fulfil, but rather through "the human ability to create, through the use of language, a public set of commitments" (Searle 2001, 183, emphasis in original). This set consists of the consequences of various speech acts we perform. It is therefore the analysis of speech acts that can illuminate the structure and conclusions of our public practical argumentation.

Throughout this paper I have largely followed Searle's (1975) wellknown taxonomy of speech acts into five broad categories (assertives/representatives, commissives, directives, expressives and declarations) rather than Austin's (1975, Ch. XII) original taxonomy (verdictives, exercitives, commissives, behabitives and expositives). Indeed, one might argue that Austin's exercitives are particularly relevant here ${ }^{34}$ :

An exercitive is the giving of a decision in favour of or against a certain course of action, or advocacy of it. It is a decision that something is to be so, as distinct from a judgement that it is so: it is advocacy that it should be so, as opposed to an estimate that it is so; (Austin 1975, 154)

Many of the illocutionary acts discussed here - orders, pieces of advice, recommendations, entreaties, pleas — are listed by Austin in this category. ${ }^{35}$ However, in line with his incipient institutional ontology, Austin delineated a somewhat more specific category of largely "legislative or executive acts": vetoes, appointments, excommunications, proclamations, authorizations, etc. (Austin 1975, Ch. XII). As such, however, the class of exercitives can

34 Austin's commissives have been unreservedly appropriated by Searle $(1975,356)$, so this is not a point of concern. Further, "I conclude..." is obviously a discursive expositive on Austin's account, a type of a speech act instrumental in "the clarifying of reasons, arguments, and communications" (Austin 1975, 162). As is clear from my arguments, I did not aim at this sort of metalinguistic characterization here.

35 In a similar vein, Corredor (2020) classifies the act of collectively "accepting a proposal" in a deliberation dialogue as an Austinian exercitive, while maintaining that (an earlier) speech act of "making a proposal" belongs to the class of verdictives. Since her work was published after this paper was originally submitted, I have no space to fully engage with her account. However, given Austin's definitions, it seems the reverse might be correct: making a proposal seems to be an exercitive, while (officially) accepting it is a verdictive.

Organon F 28 (2) 2021: 420-457 
be justifiably criticized for lacking a straightforward principle of classification and, hence, for being too heterogeneous, with many examples defying the very definition of the class: "nominating, appointing, and excommunicating are not the 'giving of a decision in favor of or against a certain course of action,' much less are they 'advocating' it. Rather they are, as Austin himself might have said, performances of these actions, not advocacies of anything" (Searle 1975, 353). Given this, Searle counts them among declarations, with all their peculiarities regarding double direction of fit, institutional preparatory conditions, void sincerity conditions, etc. Altogether, Searle's organizing effort on Austin's original ideas works well precisely in the context where some clear distinctions are needed as a background for further work.

In this context, recent work on imperative speech acts, while challenging some of the simplifications of traditional speech act analysis, sheds additional light on the "you / they" category of agents. In particular, Lance and Kukla (2013) have examined the class of speech acts they simply call "second-person calls," whose prime examples include imperatives (orders, commands), requests and entreaties. Their basic argument is that second-person calls can hardly be regarded as belonging to a unified class of directives or imperatives, characterised by the same illocutionary point-namely, to get or even oblige someone to do something - and differing mostly in strength, from meek invitations to forceful orders. Rather, Lance and Kukla maintain, "there are indefinitely many kinds of calls, with distinctive structures, whose subtleties help to constitute a rich moral and social space" (Lance and Kukla 2013, 458). According to them, especially between imperatives and requests there exist "deep differences":

It is in the nature of imperatives that they impute obligations, and in doing so, they do not present their target with a choice of whether to obey them. [...] [W] hile all calls give their targets reasons to act, different kinds of calls create different kinds of reasons, and these kinds often cannot be understood except in relation to the types of second-personal transactions that institute them. We may give the name "petitionary reasons" to the distinctive kinds of reasons created by requests - that is, those that give the one requested the right kind of reason to act that opens 
up the right kind of space of freedom, pressure, and so forth. [...] An imperative is structurally incapable of giving its target a petitionary reason to act. Petitionary reasons are not just weak obligations, nor are they obligations backed up by weak desires on the part of the requester; they are a different variety of reason altogether. (Lance and Kukla 2013, 462) ${ }^{36}$

Further, requests and invitations can also be distinguished by their pragmatic subtleties: requests amount to a favour done by the requestee to the requester, while invitations appeal to matching desires of the invitee and inviter. As a consequence, successful invitations call for gratitude from both parties ("Thanks for inviting me!"- "Thanks for coming!") whereas granted requests only from the requester - the recipient of a favor (Lance and Kukla 2013, 461).

These arguments make it obvious that a unidimensional continuum ordering action-inducing speech acts based on their illocutionary strength is merely a heuristic appealed to for the sake of the economy of exposition. As described in section 2.2, this was also the basic insight of Gauthier (1963), who without using speech act concepts such as illocutionary force or illocutionary strength, analysed the subtle differences among various directive speech acts much in the same way Lance and Kukla, and others, recently do. ${ }^{37}$ Other concerns beyond mere strength of the illocutionary point, such

36 In their account of imperatives, Condoravdi and Lauer (2012) even more emphatically criticize the view according to which "the addressee of an imperative automatically becomes committed to making the content of the imperative true." As they observe: "While this may be right for order uses, which intuitively create hearer obligations, most other uses of imperatives, even other directive uses, do not (directly) induce hearer commitments. A crucial feature of requests, pleas, warnings, etc. is that they do not create addressee commitments (though they may be uttered in the hope that the addressee takes on a commitment)." (Condoravdi and Lauer 2012, 55). Still, as observed by Lance and Kukla, and in line with the traditional speech act theory, unless the speech act is infelicitous, the hearer is expected to respond to an imperative, and the preferred response is for the hearer to get committed (grant a request, accept an invitation) or refuse commitment with a good justification ("Sorry, I can't make it, because...").

37 It is only a pity, then, that this work is completely ignored, including Gauthier's ideas connecting directive speech acts to practical argumentation.

Organon F 28 (2) 2021: 420-457 
as the mode of achievement (command vs. request) or degree of strength of the sincerity conditions (beg vs. request), can and should be factored in for a more nuanced taxonomy. ${ }^{38}$ For now, however, the crucial point is to indicate that our practical argumentation often concludes in an appeal to or a call for an action of a second person. In this way, despite all their intriguing differences, second-person calls form a category homogenous enough for the current purposes.

The current proposal also clearly allows for the practical reasoning from the second / third person's desires and goals. This might resolve some of the apparently Moorean paradoxes of directive speech acts, such as those discussed by Condoravdi and Lauer (2012):

\#Call him at home! I don't want you to but he is fine with that.

\#OK, go to Paris then since you want it so much! But, don't forget, I don't want you to.

These examples seem to demonstrate that "it is not felicitous to follow an imperative with an assertion that the realization of the content goes against the speaker's desires" (Condoravdi and Lauer 2012, 41-43).

However, such cases can be made felicitous, as long as the structure of $\mathrm{PR}$ is relative to hearer's desires. ${ }^{39}$ Good advice is often idiomaticised in English to "If I were you, I would never talk to him again." There seem to be no pragmatic inconsistency whatsoever in adding "although, as you know, I myself actually quite hate that kind of thing." But even in the case

38 "Mode of achievement" and "degree of strength of the sincerity conditions" are among the seven basic factors distinguishing various types of speech acts in Searle and Vanderveken's work. The institutional mode of authority is needed for commands, and a speaker who "begs, beseeches, or implores, [...] expresses a stronger desire than if he merely requests" (Searle and Vanderveken 1985, 19). Lance and Kukla are therefore partly wrong in attributing ignorance of these additional factors to Searle's typology of speech acts.

39 Or, even stronger, as Gauthier argues, this is the very basic condition of an advice: "It would clearly be impossible for the adviser to substitute his own practical basis in giving advice. For, from premisses about the situation, plus premisses about $m y$ aims, nothing follows at least prudentially, about what you should do" (1963, 54); cf. (van Poppel 2019). 
of straightforward grammatical imperatives, reasoning from the second person's desires conflicting the speaker's desires is pragmatically possible:

Parent to an early-adult child:

OK, go to Paris then, if you want it so much! But don't forget I've been against it all along! $!^{40}$

Overall, however, the current proposal is compatible with much of the recent work on imperative speech acts. This is the case with Condoravdi and Lauer's approach who treat imperatives - including their various illocutionary variants, from orders, pleas and requests to invitations, permissions and advice - as expressions of effective preferences of the speaker. These effective preferences are sets of possible choices structured in a consistent way from the best to the worst - a condition necessary if "the [rational] agent is to decide on a course of action" (Condoravdi and Lauer 2012, 45). These elements are included in the model of PA presented above in Section 3. Indeed, while for Condoravdi and Lauer the utterers of imperatives are committed to their effective preferences and beliefs, in the model suggested here they are committed to all the premises of the PA, including their choice of the best, or at least satisfactory, action-inducing speech act.

According to Portner $(2007 ; 2018)$ imperatives are linguistically performed via priority modals of three varieties: deontic, bouletic and teleological. As he puts it, "The idea behind the term 'priority' is that some choice is given priority over another" (Portner 2007, 355). Importantly, various subtypes of imperatives can be distinguished based on the ordering source: orders are deontic as they involve obligations of the hearer, invitations are bouletic as they appeal to the desires of the hearer, and suggestions are

40 Arguably, in this case a "permissive" rather than "directive" form of grammatical imperative is used, as argued in (Condoravdi and Lauer 2012), whereby the parent is reluctantly permitting the adult child to do something that $\mathrm{s} /$ he as a parent can no longer prohibit. Still, the same form of Moore's paradox applies here, based on the generalization that "It seems that there is a bouletic component conventionally associated with imperatives. For if it were not conventional, we would expect this constraint to be absent in scenarios in which the speaker can be assumed to not share the goals of the addressee, as in disinterested advice uses." (Condoravdi and Lauer 2012, 42). 
teleological in that they refer to the goals of the hearer. Again, the structuring of acts based on their priority in relation to desires, goals and obligations is a central element of the approach proposed here.

This is not to deny that what I offered here is hardly more than a simple matrix ordered by the agent of the action and the illocutionary strength of a speech act. Even this simple matrix, however, can help us better understand what practical argumentation is "about," that is, "why" or what "for" we argue practically. We argue to issue various speech acts: from innocuous private announcements and suggestions to strong commands and solemn joint pledges. Further careful analysis of all such speech acts, in their natural context, with their respective felicity conditions and further consequences, can sharpen our understanding of practical argument.

Therefore, we should do it.

\section{References}

Aakhus, Mark. 2006. "The Act and Activity of Proposing in Deliberation." In Engaging Argument: Selected papers from the 2005 NCA/AFA Summer Conference on Argumentation, edited by P. Riley, 402-408. Washington, DC: National Communication Association.

Aristotle. 1984. Nicomachean ethics. In The Complete Works of Aristotle, Vol. II, edited by Jonathan Barnes, 1729-1867. Princeton, NJ: Princeton University Press. https://doi.org/10.1515/9781400835850

Audi, Robert. 2006. Practical Reasoning and Ethical Decision. New York: Routledge. https://doi.org/10.4324/9780203015681

Austin, John L. 1975. How To Do things With Words. $2^{\text {nd }}$ ed. Oxford: Clarendon Press. https://doi.org/10.1093/acprof:oso/9780198245537.001.0001

Bach, Kent. 1975. "Performatives are Statements Too." Philosophical Studies 28: 229-236. https://doi.org/10.1007/BF00353970

Bach, Kent, and Robert M. Harnish. 1992. "How Performatives Really Work: A Reply to Searle." Linguistics \&3 Philosophy 15: 93-110. https://doi.org/10.1007/BF00635834

Bratman, Michael E. (2014). Shared Agency: A Planning Theory of Acting Together. Oxford: Oxford University Press. https://doi.org/10.1093/acprof:oso/9780199897933.001.0001

Broome, John. 2013. Rationality Through Reasoning. Oxford: Wiley-Blackwell. https://doi.org/10.1002/9781118609088 
Campos, Andre S. 2018. "Intergenerational Justice Today." Philosophy Compass 13 (3): 1-12. https://doi.org/10.1111/phc3.12477

Chang, Ruth. 2016. "Comparativism: The Grounds of Rational Choice." In Weighing reasons, edited by Errol Lord and Barry McGuire, 213-240. Oxford: Oxford University Press. https://doi.org/10.1093/acprof:oso/9780199315192.003.0011

Clark, Herbert H., and Thomas B. Carlson. 1982. "Hearers and Speech Acts." Language 58 (2): 332-73. https://doi.org/10.2307/414102

Condoravdi, Cleo, and Sven Lauer. 2012. "Imperatives: Meaning and Illocutionary Force." In Empirical Issues in Syntax and Semantics 9: Papers from the Colloque de Syntaxe et Sémantique à Paris 2011, edited by Christopher Piñón, 3758. Paris: CNRS.

Corredor, Cristina. 2020. "Deliberative Speech Acts: An Interactional Approach." Language $\&$ Communication 71: 136-48. https://doi.org/10.1016/j.langcom.2020.01.005

Dascal, Marcelo. 2005. "Debating with Myself and Debating with Others." In Controversies and Subjectivity, edited by Pierluigi Barrotta and Marcelo Dascal, 33-73) Amsterdam: John Benjamins. https://doi.org/10.1075/cvs.1.04das

Davidson, Donald. 1963). "Actions, Reasons, and Causes." The Journal of Philosophy 60 (23): 685-700. https://doi.org/10.2307/2023177

Eemeren, Frans H. van, and Rob Grootendorst. 1984. Speech Acts in Argumentative Discussions. Dordrecht: De Gruyter Mouton. https://doi.org/10.1515/9783110846089

Fairclough, Isabela, and Norman Fairclough. 2012. Political Discourse Analysis. London: Routledge. https://doi.org/10.4324/9780203137888

Fogal, Daniel, Daniel W. Harris, and Matt Moss, eds. 2018. New Work on Speech Acts. Oxford: Oxford University Press. https://doi.org/10.1093/oso/9780198738831.001.0001

Gauthier, David P. 1963. Practical Reasoning: The Structure and Foundations of Prudential and Moral Arguments and Their Exemplification in Discourse. Oxford: Clarendon Press.

Gilbert, Margaret. 1990. "Walking Together: A Paradigmatic Social Phenomenon." Midwest Studies in Philosophy 15: 1-14. https://doi.org/10.1111/j.14754975.1990.tb00202.x

Green, Michell S. 2009. "Speech Acts, the Handicap Principle and the Expression of Psychological States." Mind \& Language 24 (2): 139-63. https://doi.org/10.1111/j.1468-0017.2008.01357.x

Green, Mitchell S. 2017. "Conversation and Common Ground." Philosophical Studies 174: 1587-1604. https://doi.org/10.1007/s11098-016-0779-z 
Green, Mitchell S. 2018. "A Refinement and Defense of the Force/Content Distinction." In New work on speech acts, edited by Daniel Fogal, Daniel W. Harris, and Matt Moss, 99-122. Oxford: Oxford University Press.

https://doi.org/10.1093/oso/9780198738831.003.0004

Green, Mitchell S. 2020. "Speech Acts." Stanford Encyclopedia of Philosophy (Winter 2020 Edition), edited by Edward N. Zalta. Last updated September 24, 2020. https://plato.stanford.edu/archives/win2020/entries/speech-acts/

Hample, Dale. 2005. Arguing: Exchanging Reasons Face to Face. Mahwah, NJ: Lawrence Erlbaum. https://doi.org/10.4324/9781410613486

Hanks, Peter. 2018. "Types of Speech Acts." In New work on speech acts, edited by Daniel Fogal, Daniel W. Harris, and Matt Moss, 123-43. Oxford: Oxford University Press. https://doi.org/10.1093/oso/9780198738831.003.0005

Harris, Daniel W., Daniel Fogal, and Matt Moss. 2018. "Speech Acts: The Contemporary Theoretical Landscape." In New work on speech acts, edited by Daniel Fogal, Daniel W. Harris, and Matt Moss, 1-39. Oxford: Oxford University Press. https://doi.org/10.1093/oso/9780198738831.003.0001

Hitchcock, David. 2002. "Pollock on Practical Reasoning." Informal Logic 22 (3): 247-56. https://doi.org/10.22329/il.v22i3.2591

Houtlosser, Peter. 1998. "Points of View." Argumentation 12 (3): 387-405. https://doi.org/10.1023/A:1007770813424

Ihnen Jory, Constanza. 2016. "Negotiation and Deliberation: Grasping the Difference." Argumentation 30 (2): 145-65. https://doi.org/10.1007/s10503-014-9343-1

Jacobs, Scott. 1989. "Speech Acts and Arguments." Argumentation 3 (4): 345-65. https://doi.org/10.1007/BF00182603

Jacobs, Scott, and Sally Jackson. 1983. "Strategy and Structure in Conversational Influence Attempts." Communication Monographs 50 (4): 285-304. https://doi.org/10.1080/03637758309390171

Kauffeld, Fred J. 1998. "Presumptions and the Distribution of Argumentative Burdens in Acts of Proposing and Accusing." Argumentation 12 (2): 245-66. https://doi.org/10.1023/A:1007704116379

Lance, Mark, and Rebecca Kukla. 2013. "'Leave the Gun; Take the Cannoli': The Pragmatic Topography of Second-person Calls." Ethics 123 (3): 456-78. https://doi.org/10.1086/669565

Levinson, Stephen C. 1988. "Putting Linguistics on a Proper Footing: Explorations in Goffman's concepts of participation." In Erving Goffman: Exploring the Interaction Order, edited by Paul Drew, and Anthony Wootton, 161-227. Cambridge, Mass.: Polity Press.

Lewiński, Marcin. 2015. "Practical Reasoning and Multi-party Deliberation: The Best, the Good Enough and the Necessary." In The Eighth Conference of the International Society for the Study of Argumentation (ISSA), edited by Bart 
Garssen, David Godden, Gordon Mitchell and A. Francisca Snoeck Henkemans, 851-62. Amsterdam: SicSat.

Lewiński, Marcin. 2017. "Practical Argumentation as Reasoned Advocacy." Informal Logic 37 (2): 85-113. https://doi.org/10.22329/il.v37i2.4775

Lewiński, Marcin. 2019. "Argumentative Discussion: The Rationality of What?" TOPOI: An International Review of Philosophy 38 (4): 645-58. https://doi.org/10.1007/s11245-015-9361-0

Lewiński, Marcin. 2021. "Illocutionary Pluralism." Synthese, https://doi.org/10.1007/s11229-021-03087-7

Lewiński, Marcin, and Dima Mohammed. 2019. "The 2015 Paris Climate Conference: Arguing for the fragile consensus in global multilateral diplomacy." Journal of Argumentation in Context 8 (1): 65-90. https://doi.org/10.1075/jaic.18017.lew

McBurney, Peter, David Hitchcock, and Simon Parsons. 2007. "The Eightfold Way of Deliberation Dialogue." International Journal of Intelligent Systems 22 (1): 95-132. https://doi.org/10.1002/int.20191

Mercier, Hugo, and Dan Sperber. 2011. "Why Do Humans Reason? Arguments for an Argumentative Theory." Behavioral and Brain Sciences 34 (2): 57-74. https://doi.org/10.1017/S0140525X10000968

Pagin, Peter. 2016. "Assertion." In Stanford Encyclopedia of Philosophy (Winter 2016 Edition), edited by Edward N. Zalta. Last updated December 31, 2016. https://plato.stanford.edu/archives/win2016/entries/assertion/

Paglieri, Fabio. 2013. "Choosing to Argue: Towards a Theory of Argumentative Decisions." Journal of Pragmatics 59 (Part B): 153-63. https://doi.org/10.1016/j.pragma.2013.07.010

Pollock, John L. 1995. Cognitive Carpentry: A Blueprint for how to Build a Person. Cambridge, Mass.: MIT Press. https://doi.org/10.7551/mitpress/1887.001.0001

Poppel, Lotte van. 2019. "Anticipating Resistance to Health Advice: A Speech Act Perspective." Discourse Processes 56 (3): 256-69. https://doi.org/10.1080/0163853X.2018.1470440

Portner, Paul. 2007. "Imperatives and Modals". Natural Language Semantics 15: 351-83. https://doi.org/10.1007/s11050-007-9022-y

Portner, Paul. 2018. Mood. Oxford: Oxford University Press. https://doi.org/10.1093/oso/9780199547524.001.0001

Reimer, Marga. 1995. "Performative Utterances: A Reply to Bach and Harnish." Linguistics and Philosophy 18 (6): 655-75. https://doi.org/10.1007/BF00983301

Rodrigues, Soledade, Marcin Lewiński, and Mehmet A. Üzelgün. 2019. "Environmental Manifestoes: Argumentative Strategies in the Ecomodernist Manifesto." 
Journal of Argumentation in Context 8 (1): 12-39.

https://doi.org/10.1075/jaic.18036.rod

Sbisà, Marina. 2007. "How to Read Austin." Pragmatics 17 (3): 461-73.

https://doi.org/10.1075/prag.17.3.06sbi

Searle, John R. 1969. Speech Acts. An Essay in the Philosophy of Language. Cambridge: Cambridge University Press.

https://doi.org/10.1017/CBO9781139173438

Searle, John R. 1975. "A Taxonomy of Illocutionary Acts." In Language, mind, and knowledge. Minnesota studies in the philosophy of science, Volume 7, edited by Keith Günderson, 344-69. Minneapolis: University of Minnesota Press.

Searle, John R. 1989. "How Performatives Work." Linguistics and Philosophy 12: 535-58. https://doi.org/10.1007/BF00627773

Searle, John R. 2001. Rationality in Action. Cambridge, Mass.: MIT Press. https://doi.org/10.7551/mitpress/5759.001.0001

Searle, John R. 2010. Making the Social World: The Structure of Human Civilization. Oxford: Oxford University Press. https://doi.org/10.1093/acprof:osobl/9780195396171.001.0001

Searle, John R., and Daniel Vanderveken. 1985. Foundations of Illocutionary Logic. Cambridge: Cambridge University Press.

Stalnaker, Robert. 2002. "Common Ground." Linguistics and Philosophy 25 (5-6): 701-21. https://doi.org/10.1023/A:1020867916902

Strawson, Peter F. 1964. "Intention and Convention in Speech Acts." The Philosophical Review 73 (4): 439-60. https://doi.org/10.2307/2183301

Tuomela, Raimo. 2013. Social Ontology: Collective Intentionality and Group Agents. Oxford: Oxford University Press. https://doi.org/10.1093/acprof:oso/9780199978267.001.0001

Urmson, J. O. 1977. "Performative Utterances." Midwest Studies in Philosophy 2: 120-27. https://doi.org/10.1111/j.1475-4975.1977.tb00033.x

Walton, Douglas. 2006. "How to Make and Defend a Proposal in a Deliberation Dialogue." Artificial Intelligence and Law 14 (3): 177-239.

https://doi.org/10.1007/s10506-006-9025-x

Walton, Douglas. 2007. "Evaluating Practical Reasoning." Synthese 157 (2): 197240. https://doi.org/10.1007/s11229-007-9157-x

Watson, Gary. 2004. "Asserting and Promising." Philosophical Studies 117: 57-77. https://doi.org/10.1023/B:PHIL.0000014525.93335.9e

Williamson, Timothy. 1996. "Knowing and Asserting." Philosophical Review 105: 489-523. https://doi.org/10.2307/2998423

Witek, Maciej. 2021. "Self-Expression in Speech Acts." Organon F 28 (2): 326-59. https://doi.org/10.31577/orgf.2021.28204 